medRxiv preprint doi: https://doi.org/10.1101/2021.03.15.21253590; this version posted March 17, 2021. The copyright holder for this preprint (which was not certified by peer review) is the author/funder, who has granted medRxiv a license to display the preprint in It is made available under a CC-BY-NC-ND 4.0 International license

\title{
An integrated analysis of contact tracing and genomics to assess the efficacy of travel restrictions on SARS-CoV-2 introduction and transmission in England from June to September, 2020
}

${ }^{*}$ Dinesh Aggarwal ${ }^{1,2,3,4}$, Andrew J. Page ${ }^{5, \wedge}$, Ulf Schaefer ${ }^{2, \wedge}$, George M. Savva ${ }^{5}$, Richard Myers $^{2}$, Erik Volz ${ }^{6}$, Nicholas Ellaby ${ }^{2}$, Steven Platt ${ }^{2}$, Natalie Groves ${ }^{2}$, Eileen Gallaghar ${ }^{2}$, Niamh M. Tumelty ${ }^{7}$, Thanh Le Viet ${ }^{5}$, Gareth J. Hughes ${ }^{8}$, Cong Chen ${ }^{2}$, Charlie Turner ${ }^{2}$, Sophie Logan ${ }^{9}$, Abbie Harrison ${ }^{2}$, The COVID-19 Genomics UK (COG-UK) Consortium ${ }^{10, \#,}$ Sharon J. Peacock ${ }^{1,2,3,4}$, Meera Chand ${ }^{2 \wedge}$, *Ewan M. Harrison ${ }^{1,2,4,11^{\wedge \wedge}}$

\section{Affiliations}

1. University of Cambridge, Department of Medicine, Cambridge, UK.

2. Public Health England, 61 Colindale Ave, London, NW9 5EQ, UK.

3. Cambridge University Hospital NHS Foundation Trust, Cambridge, UK.

4. Wellcome Sanger Institute, Hinxton, Cambridge, UK.

5. Quadram Institute Bioscience, Norwich Research Park, Norwich, NR4 7UQ, UK.

6. Imperial College London, Department of Infectious Disease Epidemiology, London, UK.

7. University of Cambridge, Cambridge University Libraries, Cambridge, UK

8. Public Health England National Infections Service, Field Service, Leeds, UK.

9. Public Health England, National Infections Service, Field Service, Nottingham, UK.

10. https://www.cogconsortium.uk

11. University of Cambridge, Department of Public Health and Primary Care, Cambridge, UK.

\# Full list of consortium names and affiliations are in the appendix

$\wedge$ Contributed equally

$\wedge^{\wedge}$ Contributed equally (joint senior authors)

* corresponding authors:

Dr Dinesh Aggarwal, University of Cambridge, Department of Medicine, Cambridge, UK. Email: dinesh.aggarwal@nhs.net

Dr Ewan Harrison, Wellcome Sanger Institute, Hinxton, Cambridge, UK. Email: eh6@sanger.ac.uk

NOTE: This preprint reports new research that has not been certified by peer review and should not be used to guide clinical practice. 
medRxiv preprint doi: https://doi.org/10.1101/2021.03.15.21253590; this version posted March 17, 2021. The copyright holder for this preprint (which was not certified by peer review) is the author/funder, who has granted medRxiv a license to display the preprint in It is made available under a CC-BY-NC-ND 4.0 International license .

\section{Abstract}

Background: Mitigation of SARS-CoV-2 transmission from international travel is a priority. Travellers from countries with travel restrictions (closed travel-corridors) were required to quarantine for 14 days over Summer 2020 in England. We describe the genomic epidemiology of travel-related cases in England and evaluate the effectiveness of this travel policy.

Methods: Between 27/05/2020 and 13/09/2020, probable travel-related SARS-CoV-2 cases and their contacts were identified and combined with UK SARS-CoV-2 sequencing data. The epidemiology and demographics of cases was identified, and the number of contacts per case modelled using negative binomial regression to estimate the effect of travel restriction, and any variation by age, sex and calendar date. Unique travel-related SARS-CoV-2 genomes in the COG-UK dataset were identified to estimate the effect travel restrictions on cluster size generated from these. The Polecat Clustering Tool was used to identify a travelrelated SARS-CoV-2 cluster of infection.

Findings: 4,207 travel-related SARS-CoV-2 cases are identified. 51.2\% (2155/4207) of cases reported travel to one of three countries; $21.0 \%$ (882) Greece, 16.3\% (685) Croatia and $14.0 \%$ (589) Spain. Median number of contacts per case was 3 (IQR 1-5), and greatest for the $16-20$ age-group (9.0, 95\% C.I.=5.6-14.5), which saw the largest attenuation by travel restriction. Travel restriction was associated with a $40 \%$ (rate ratio $=0.60,95 \%$ C.I. $=0.37$ $0.95)$ lower rate of contacts. $827 / 4207(19.7 \%)$ of cases had high-quality SARS-CoV-2 genomes available. Fewer genomically-linked cases were observed for index cases related to countries with travel restrictions compared to cases from non-travel restriction countries (rate ratio $=0.17,95 \%$ C.I. $=0.05-0.52$ ). A large travel-related cluster dispersed across England is identified through genomics, confirmed with contact-tracing data.

Interpretation: This study demonstrates the efficacy of travel restriction policy in reducing the onward transmission of imported cases.

Funding: Wellcome Trust, Biotechnology and Biological Sciences Research Council, UK Research \& Innovation, National Institute of Health Research, Wellcome Sanger Institute. 
medRxiv preprint doi: https://doi.org/10.1101/2021.03.15.21253590; this version posted March 17, 2021. The copyright holder for this preprint (which was not certified by peer review) is the author/funder, who has granted medRxiv a license to display the preprint in It is made available under a CC-BY-NC-ND 4.0 International license .

\section{RESEARCH IN CONTEXT}

\section{Evidence before this study}

We searched PubMed, medRxiv, bioRxiv, Web of Science and Scopus for the terms (COVID-19 OR SARS-COV-2) AND (imported or importation) AND (sequenc* OR genom* or WGS). We filtered the 55 articles identified through this search and rejected any that did not undertake SARS-CoV-2 sequencing as part of an epidemiological investigation for importation into a different country. The remaining 20 papers were reviewed in greater detail to understand the patterns of importation and the methods used in each case.

\section{Added value of this study}

This is the first published study on importations of SARS-CoV-2 into England using genomics. Plessis et al., (2021) used a predictive model to infer the number of importations in to the UK from all SARS-CoV-2 genomes generated before 26th June 2020. The current study assesses the period 27/05/2020 to 13/09/2020 and presents findings of case-reported travel linked to genomic data. Two unpublished reports exist for Wales and Scotland, although only examine a comparatively small number of importations.

\section{Implications of all the available evidence}

This large-scale study has a number of findings that are pertinent to public health and of global significance, not available from prior evidence to our knowledge. The study demonstrates travel restrictions, through the implementation of 'travel-corridors', are effective in reducing the number of contacts per case based on observational data. Age has a significant effect on the number of contacts and this can be mitigated with travel restrictions. Analysis of divergent clusters indicates travel restrictions can reduce the number of onwards cases following a travel-associated case. Analysis of divergent clusters can allow for importations to be identified from genomics, as subsequently evidenced by cluster characteristics derived from contact tracing. The majority of importations of SARS-CoV-2 in England over Summer 2020 were from coastal European countries. The highest number of cases and onward contacts were from Greece, which was largely exempt from self-isolation requirements (bar some islands in September at the end of the study period). Systematic monitoring of imported SARS-CoV-2 cases would help refine implementation of travel restrictions. Finally, along with multiple studies, this study highlights the use of genomics to monitor and track importations of SARS-CoV-2 mutations of interest; this will be of particular use as the repertoire of clinically relevant SARS-CoV-2 variants expand over time and globally. 
medRxiv preprint doi: https://doi.org/10.1101/2021.03.15.21253590; this version posted March 17, 2021. The copyright holder for this preprint (which was not certified by peer review) is the author/funder, who has granted medRxiv a license to display the preprint in It is made available under a CC-BY-NC-ND 4.0 International license .

Introduction

129 A new coronavirus related disease (COVID-19) was first reported in Wuhan, China (2) in

130 December 2019, with the causative virus identified as a novel coronavirus SARS-CoV-2 (3).

131 Since then, SARS-CoV-2 has been imported into virtually every country and region in the

132 world. Understanding and tracking the sources of importations can give important

133 information for policy makers, and for managing the pandemic, by informing policies aimed

134 at reducing the further spread of virus.

136 Public health measures can help mitigate and suppress the spread of the virus, but the 137 threat of importations will remain. The available brakes on imported SARS-CoV-2 cases 138 include travel bans, quarantine measures, and testing of returning travellers. These can 139 apply to all countries or targeted to high-risk countries, for variable durations, and with 140 variable degree of enforcement. In England, travel restrictions were assigned on a country 141 by country basis from 6 July 2020 entailing the use of 'travel-corridors'; travellers returning 142 from countries that were on the travel restrictions list (with 'closed travel-corridors') (4) were 143 required to quarantine for 14 days (reduced to 10 days on $15 / 12 / 20$ ), or from the $15^{\text {th }}$

144 December 2020, choose to quarantine for 5 days and then pay for a SARS-CoV-2 diagnostic 145 test (Figure 1). This policy aims to limit onwards transmission of SARS-CoV-2, and as a 146 secondary outcome possibly deter travel to those countries. Upon identification of an 147 imported case, contact tracing and quarantine/self-isolation measures can limit onwards 148 transmission. The CORSAIR study reported that $18.2 \%$ of individuals adhered to general 149 SARS-CoV-2 self-isolation guidance recommended by Public Health England in the UK (5).

150 The PHE Isolation Assurance Service however have identified up to $97 \%$ self-reported compliance with travel-specific self-isolation guidance (6). These data do not include countries exempt from quarantine, contact-tracing data or link to genomic data to evaluate travel-related clusters.

Studies from numerous countries have used genome sequencing to complement epidemiological investigations in order to characterise importations of SARS-CoV-2

157 (Supplementary Table 1). Primarily these are in-depth case reports on small datasets but 158 demonstrate the utility of genomics combined with contact tracing. Genomic sequencing of returning travellers was useful in allowing for the first case of reinfection of SARS-CoV-2 in

160 the world to be identified in Hong Kong (7) and identify a new variant of SARS-CoV-2 161 (B.1.177/20A.EU1, variant A222V) (8).

163 This study combines contact-tracing data from National Health Service (NHS) Test and 164 Trace (T\&T) for probable importation cases with genomic data made available through the 
medRxiv preprint doi: https://doi.org/10.1101/2021.03.15.21253590; this version posted March 17, 2021. The copyright holder for this preprint (which was not certified by peer review) is the author/funder, who has granted medRxiv a license to display the preprint in It is made available under a CC-BY-NC-ND 4.0 International license .

165 COVID-19 Genomics UK (COG-UK) consortium (9), which receives samples from NHS

166 hospital diagnostic labs and mass community testing labs (UK Lighthouse labs network)

167 across the UK. We aimed to characterise the known imported cases and the effectiveness of

168 travel restrictions on onwards transmission.

170 A total of 4,207 SARS-CoV-2 positive importation cases were analysed, along with 18,856

171 contacts, of which 888 sequenced genomes were available for comparison to all UK

172 genomic data $(131,387$ sequences from the UK and in the COG-UK dataset by 5 December

173 2020). The number of contacts reported by a case was used as an indicator of adherence to

174 quarantining.

\section{Methods and materials}

176

Contact tracing and case identification

178 Contact-tracing data was obtained from T\&T. All cases and contacts had a field for

179 demographic data, but this was not always reported (Table 2 and Supplementary Table 3).

180 'Highly probable' travel-related cases were defined as individuals who reported international

181 travel as an activity in the two days before symptom onset/testing. On 12/08/2020 the

182 additional facility to report international travel in the seven days prior to symptom

183 onset/testing became available, and also included in this study and defined as 'probable'

184 travel-related cases.

185

186 Cases were asked to provide details of all contacts for activities in the 2 days prior to 187 onset/testing up to completing the system which were gathered. If any contacts become

188 cases they would then also be included in T\&T data as a case separately, but if they did not

189 report direct travel themselves, then they would not meet the definition for a travel-

190 associated case.

191

\section{Case identification from T\&T data}

193 Data included free-text destination city or country. A freetext country and city search with a 194 custom python script on travel-related T\&T was used to identify destination country. Results 195 and remaining entries were manually checked and corrected (see Supplementary methods 196 for more details).

198 Clinical samples, Genome sequencing and Quality Control

199 Clinical samples were collected passively as part of national SARS-CoV-2 testing. This

200 included both community testing through lighthouse labs and testing through hospital 
medRxiv preprint doi: https://doi.org/10.1101/2021.03.15.21253590; this version posted March 17, 2021. The copyright holder for this preprint (which was not certified by peer review) is the author/funder, who has granted medRxiv a license to display the preprint in It is made available under a CC-BY-NC-ND 4.0 International license.

201 diagnostic labs. Samples were sequenced at one of seventeen COG-UK sequencing sites

202 (Figure 1). The samples were prepared for sequencing using either the ARTIC (10) or

203 veSeq (11) protocols, and were sequenced using Illumina or Oxford Nanopore platforms. All

204 samples were uploaded to and processed through COVID-CLIMB pipelines $(12,13)$.

205 Genomes were aligned to the Wuhan Hu-1 reference genome (MN908947.3). Genomes

206 which contained more than $10 \%$ missing data were excluded from further analysis to ensure

207 high quality phylogenetic analysis.

Lineages and minor variants

210 Global and UK Lineages (14) were assigned to each genome using Pangolin

211 (https://github.com/cov-lineages/pangolin) with analysis performed on COVID-CLIMB (13).

212 Minor variants were pre-defined within the COG-UK database using type_variants

213 (https://github.com/cov-ert/type_variants).

214

215 Identification of extinct and unique genomes

216 The 827 high-quality travel-related genomes were compared to the COG-UK dataset on

217 16/10/2020. Genomes were only compared to other genomes with the same UK lineage

218 assigned by COG-UK, since we assume that no relatedness relevant to transmission exists

219 between genomes of different UK lineages. A 'unique' genome in the community was

220 deemed to be one that was known to be from a travel-related case and either: (1) A UK

221 lineage that had not been sampled in the previous 4 weeks in the UK, (2) >3 SNPs distance

222 to the closest relative in the COG-UK dataset.

223 Within the same UK lineage we identified those genomes sampled within 4 weeks prior to

224 the genome of interest. We determined the minimum SNP distance between the sequence

225 of interest and these genomes. 'Unique' genomes were compared to sequences that were

226 generated in the COG-UK dataset within 2 and 4 weeks after their sampling date, to identify

227 samples with the same UK lineage and within 2 SNPs. These would represent onward

228 transmission or further introductions of similar genomes. The analysis was run with an in-

229 house custom Python script developed by US and RM. Further detail in supplementary

230 methods.

Identification of a travel-related SARS-CoV-2 cluster

233 We used the Polecat clustering tool (https://cog-uk.github.io/polecat) to systematically

234 identify outliers in COG-UK genomic dataset and link to contact-tracing data. 
medRxiv preprint doi: https://doi.org/10.1101/2021.03.15.21253590; this version posted March 17, 2021. The copyright holder for this preprint (which was not certified by peer review) is the author/funder, who has granted medRxiv a license to display the preprint in It is made available under a CC-BY-NC-ND 4.0 International license .

Statistical analysis

237 All models were estimated using the glmmTMB package (version 1.0.1) (15) with marginal 238 means and effects calculated using the emmeans package (1.5.2-1) (16) for $R$ (version

239 3.5.1) (17). Figures were generated using $R$ (version 4.0.2) and Microsoft Excel (version

240 1908). The number of contacts per case was modelled using negative binomial regression

241 analysis, to estimate the effect of travel restriction, and whether this varied by age-group,

242 sex of the index case and calendar date. Travel destination and ethnic group were included

243 as covariates (as random effects). A similar approach was taken when estimating the effect

244 of travel restriction on genomic cluster size.

Role of the funding source

247 The funder of the study had no role in study design, data collection, data analysis, data

248 interpretation, or writing of the report.

249 Results

250 From $17 / 03 / 20-04 / 07 / 20$ the Foreign \& Commonwealth Office advised against all non251 essential travel worldwide (18). From the 04/07/20 - 01/02/21 travel corridors to countries 252 deemed to be low risk for COVID-19 disease (subject to assessment and change) were 253 established in which returning travellers were no-longer required to quarantine. Persons 254 returning from countries outside this list (except for exemptions e.g. specific employment) 255 were required to quarantine. We sought to both gauge the impact of this policy and to 256 attempt to quantify the numbers of onward transmissions using genomic epidemiology.

258 Between 27/05/2020 and 13/09/2020, using contact-tracing data for cases who have tested 259 positive for SARS-CoV-2, we identified 4,207 travel-related cases (Figure 1). Supplementary 260 tables 2 and 3 show the case characteristics.

262 Travel to European countries accounted for $85.9 \%$ (3612/4207) of cases, of which $51.2 \%$ 263 (2155/4207) had visited one of Greece (21.0\%, 882/4207), Croatia (16.3\%, 685/4207) and 264 Spain (14.0\%,589/4207) (Figure 2 and Table 2). For 284 cases the country of travel was 265 unclear or unknown. Travel restrictions were first eased on 03/07/2020; $2.9 \%$ of travelrelated cases were recorded before this date. For the countries associated with the highest numbers of imports, the duration of the peak of imported cases differs, with variable

268 association with changes in travel restriction policy (Figure 3). Geographically variations in 269 imported cases across England were apparent, with the greatest number in Greater London $270(28.6 \%, 1205 / 4207)$ (Figure 2, Supplementary Figures 1 and 2, and Supplementary Table $2713)$. 
medRxiv preprint doi: https://doi.org/10.1101/2021.03.15.21253590; this version posted March 17, 2021. The copyright holder for this preprint (which was not certified by peer review) is the author/funder, who has granted medRxiv a license to display the preprint in It is made available under a CC-BY-NC-ND 4.0 International license .

272 The median number of reported contacts per travel-associated case was 3 (IQR 1-5), with a

273 maximum of 172 . Overall, travel restriction reduced the number of contacts per case by $40 \%$

274 (rate ratio (R.R.) $=0.60,95 \%$ C.I. $=0.37-0.95)$. The mean number of contacts (adjusting and

275 averaging over all over covariates) was 5.85 when no travel restriction was in place and 3.50

276 when there was. The effect of travel restriction varied significantly with age-group and over

277 time (Supplementary Table 4 and Figure 4). The number of contacts per case was greatest

278 for the 16-20 age-group without travel restriction with a marginal mean of 9.0 (95\% C.I.=5.6-

$27914.5)$ but with restriction reduced to 4.7 (95\% C.I.=3.9-5.7), and similar to other age-groups.

280 After adjusting for all other covariates the numbers of contacts per imported case was

281 roughly half in September compared to May, June and July, whether or not a travel

282 restriction was in place.

Transmission patterns identified by analysis of traveller SARS-CoV-2 genomes

We next sought to quantify onward transmission from an imported case using genomics. High-quality sequencing data was available for $827 / 4207$ (19.7\%) of cases (Figure 1) and demographics of the sequenced cases was broadly similar to the entire travel-related cohort (Supplementary Table 3).

$186 / 827$ (22.4\%) imported cases had viral lineages that were sufficiently unique in the COGUK dataset to monitor onward spread. Of these, 146/186 isolates had not been sampled in the entire UK dataset in the 4 weeks prior and 40/186 isolates were $>3$ SNPs to their closest matching sequence in the UK dataset.

To compare the effect of travel restrictions on the subsequent spread of likely imported cases (excluding 18/186 cases before 14/07/2020 to ensure the dates of cases with and without a travel restriction overlapped), the entire COG-UK dataset was interrogated to identify isolates within 2 SNPs of these distinct imported cases during the period 0-2 and 0-4 weeks following the importation case. The number of subsequent cases detected during the four weeks since the unique index case increased from a mean of 1.2 new cases where a travel restriction was in place to 11.3 cases where there was not. The proportions of cases leading to a subsequent newly detected case (e.g. likely transmission), and the number of new cases where at least one is detected are shown in Figure 5. Overall, 56/168 of genomes from cases that were genetically unique were detected in subsequent cases (up to four weeks later). Among cases diagnosed after returning from a country where a travel restriction was in place, $25 \%$ of (20/81) were detected in later cases (up to four weeks later), rising to $41 \%(29 / 71)$ when cases were imported from a country without a travel restriction. 
medRxiv preprint doi: https://doi.org/10.1101/2021.03.15.21253590; this version posted March 17, 2021. The copyright holder for this preprint (which was not certified by peer review) is the author/funder, who has granted medRxiv a license to display the preprint in It is made available under a CC-BY-NC-ND 4.0 International license .

309 number of subsequent cases matching each genome (range 1 to 210, IQR 0-4) with a small

310 number of imported cases corresponding to large numbers of subsequent cases (Figure 5).

312 There was some evidence that imported cases with higher numbers of contacts gave rise to

313 more cases in the subsequent month (Figure 5). Although the number of cases with any

314 subsequent matching genome was not affected by the number of contacts, the average

315 number of subsequent cases detected was substantially higher when the index case had

316 five or more contacts (mean=10.8) compared to none (mean=2.8) or 1 to 4 contacts

317 (mean=1.7).

319 To estimate the effect of travel restriction on spread, considering possible confounding

320 effects of calendar date and the mediating effect of reported contacts of the index case, and

321 to test the statistical significance of observed effects, a series of negative binomial

322 regression models were fitted (Figure 5 and Supplementary Table 5). In the four weeks

323 following the index case, fewer genomically-linked cases were reported when the index case

324 was imported from a country with travel restrictions compared to cases from a non-travel

325 restriction country (R.R. $=0.17,95 \% \mathrm{Cl}=0.05-0.52)$. When the number of contacts of the

326 index case was included in the model, this rate ratio was attenuated slightly toward 1

327 (R.R. $=0.25 ; 0.08-0.81)$ suggesting a limited mediating effect of the number of contacts of the

328 index case. The effect of contacts was still seen, but the rate of subsequent cases (over four

329 weeks) with the same genome was 4.0 (1.1-15.1) times higher for index cases with five or

330 more reported contacts compared to those with none.

332 Genomic identification of a large imported cluster

333 The Polecat Clustering tool (https://cog-uk.github.io/polecat) was used to analyse genomes

334 in UK data on 14 September 2020. An outlier cluster was observed (Supplementary Figure

335 3). This cluster (UK1897) was associated with high diversity with a long stem length

336 compared to samples from the UK, suggesting that this lineage evolved outside the UK. The

337 geographic distribution of this lineage is demonstrated in Supplementary Figure 4, likely

338 representing multiple importations across the UK (Supplementary Figure 4). This cluster

339 contained the D614G mutation but no others associated with increased transmission. The

340 root of the cluster was associated with a Swiss phylotype when linked to data in GISAID.

341 During the course of the study period (04/08/2020 to 14/09/2020) there were 304 genomes.

342 These were linked to 238 individuals, of whom 159 could be linked to a contact-tracing

343 record. 143/159 had contact-tracing information indicating international travel or not. 72/143

$344(50.3 \%)$ individuals were linked to international travel and associated with ten, 
medRxiv preprint doi: https://doi.org/10.1101/2021.03.15.21253590; this version posted March 17, 2021. The copyright holder for this preprint (which was not certified by peer review) is the author/funder, who has granted medRxiv a license to display the preprint in It is made available under a CC-BY-NC-ND 4.0 International license .

dispersed European countries (four individuals had travel to more than one European Country) and most commonly Croatia (35/72, 48.6\%) (Supplementary Figure 5). A further 4 cases were identified as contacts of individuals who had reported travel to mainland Europe. There is a trend towards an increased proportion of cases that do not report travel over time, and possibly representing dispersion and onwards transmission locally of this lineage (Supplementary Figure 6).

\section{Lineage diversity of imported SARS-CoV-2 cases}

The 827 imported genomes reflected 238 UK lineages (see Supplementary Materials), of which 214 were seen less than 5 times (142 singletons) and 24 were seen 5 or more times (Supplementary Table 6). The most commonly observed were UK5 (152 genomes, 18.4\%) and UK1897 (73 genomes, 8.8\%). There were 39 global lineages within the genomes. The most commonly observed lineages were B.1.1 (159 genomes, 19.2\%) and B.1.177 (128 genomes, 15.5\%) (Supplementary Tables 7 and 8). Further, potentially functionally important mutations were identified (Supplementary Table 9 and Supplementary Figure 8): D614G, 824/827 (99.6\%) cases; N439K, 65/827 (7.86\%) of cases; A222V, 131/827 (15.84\%) of cases. $\Delta \mathrm{H} 69 / \mathrm{V} 70$ was identified in 53 cases associated with lineage B.1.258. We evaluated the introduction of A222V (B.1.177) over time, demonstrating a clear epidemiological link to Spain through contact tracing (Supplementary Figure 9). By the end of the study period, this variant was introduced from 16 separate countries indicating dispersion across Europe (Supplementary Figures 10). The mutations co-occur, with the proportion of cases represented by these combinations varying over time (Supplementary Figure 11).

\section{Discussion}

We demonstrate, through the analysis of both contact-tracing data and the use of genomics, that travel restrictions (use of travel corridors) reduced the detected linked cases of SARSCOV-2. From $27 / 05 / 2020$ to $13 / 09 / 2020$, $85.9 \% \%$ of importations were from European countries with three countries accounting for $51.2 \%$ of all imported cases. Along with travel restriction, age was a significant determinant of onwards contacts, and this effect was mitigated with closing travel corridors. After a period of national lockdown, systematic monitoring of imported genomes can identify sequences that are sufficiently unique and provide utility for monitoring of onwards transmission.

Whilst the study period covers nearly 5 months, the importations are concentrated after the implementation of travel corridors. The peaks for imports for each country occur at different 
medRxiv preprint doi: https://doi.org/10.1101/2021.03.15.21253590; this version posted March 17, 2021. The copyright holder for this preprint (which was not certified by peer review) is the author/funder, who has granted medRxiv a license to display the preprint in It is made available under a CC-BY-NC-ND 4.0 International license .

382 times and with different epidemic curves. For the most common destination, barring Spain, 383 imported cases appear to reduce after country-specific travel restrictions. Importations from

384 Greece came at the end of August and continued into September, with the steepest of all curves. No travel restrictions were imposed on Greece during this time period and it was the source of greatest imported SARS-CoV-2 cases during this study period. This highlights the need for active surveillance of imported cases of SARS-CoV-2 for the introduction of travel corridors in a timely manner. London accounts for $15.4 \%$ of the population in England (19), but had $28.6 \%$ of the imports, possibly reflecting a younger age demographic. The overall R0 remained largely similar to other parts of the country during the study period potentially indicating imports are unlikely to have had a substantial impact on onward infection rates (20). Other explanations may include a small possible effect of higher seropositivity rates in London $(17.5 \%, 27 / 4 / 2020,(21))$ from the first wave of SARS-CoV-2 infections in England seen and a potential lower detection rate in London.

The number of onwards contacts are significantly reduced by the introduction of travel restrictions. Age is also a significant determinant of onwards contacts, with the 16-20 year old age-group representing the greatest number of travel-related cases and onwards contacts. This identifies an opportunity to direct public health awareness campaigns to younger travellers, with the intention to promote behaviours that will reduce the risk of SARS-CoV-2 acquisition and enhance compliance with quarantine on return to the UK.

The use of genomic sequencing, specifically after a period of national lockdown, allowed identification of a cohort of unique genomes that could be monitored for cluster growth. The cluster size for genomes that were related to a country without travel restrictions was significantly higher than those related to countries under travel restriction guidance. Further, when comparing the number of genomes in a cluster to the number of contacts that their respective cases reported, there was a trend towards a positive correlation suggesting selfisolation is effective. The total effect of travel restrictions was not explained by forward contacts alone and it is a possible that a reduction in the absolute number of individuals travelling to countries with travel restrictions also contributes to this.

413 The Polecat Clustering Tool highlighted a cluster that developed largely through travel to 414 Croatia. Programmatic analysis of genomics data can therefore identify putative importation 415 clusters. Integration with contact-tracing information was vital for the true picture of the 416 sources of introduction and the subsequent spread, due to the SARS-CoV-2 sequencing 417 bias observed globally. In this instance an introduced lineage was associated with wide418 spread dispersal and onward transmission during a period when England had limited social 
medRxiv preprint doi: https://doi.org/10.1101/2021.03.15.21253590; this version posted March 17, 2021. The copyright holder for this preprint (which was not certified by peer review) is the author/funder, who has granted medRxiv a license to display the preprint in It is made available under a CC-BY-NC-ND 4.0 International license .

419 distancing measures. The lineage, B.1.160, associated with this cluster is not associated 420 with increased transmissibility but this study highlights a supplementary method for the 421 detection and monitoring of expanding imported clusters and could prove particularly useful

422 for the investigation of introduced variants of concern.

423

424 Our study is subject to multiple limitations. The COG-UK dataset has a limited sequencing coverage across England and cluster sizes detected will under-estimate absolute numbers

426 (Supplementary Figure 12). The dates of country-specific travel restriction guidance was

427 aligned with the date of travel-related case sampling, the earliest date reliably available. The

428 effect of this should not however markedly affect results or conclusions; the period of travel

429 restrictions are long and the effect size seen is large and therefore this discrepancy is

430 unlikely to account for the significant difference observed. Further, most countries

431 accounting for the imported SARS-CoV-2 cases went into a period of a travel restriction over

432 the study period; by using a date later than the date of return from travel, we are more likely

433 to over-represent contacts for countries under 'travel-restriction' guidance. Our study

434 evaluates a period of time following a national lockdown and the associated reduced travel

435 would likely exaggerate the diversity of genomes when compared with the COG-UK dataset.

436 Outcomes such as travel and the number of contacts are self-reported by cases which will

437 have inherent biases. Finally, there will be an artificial reduction in cases at the end of the

438 study period when accounting for case incubation period, testing and report, with data

439 provided 3 days after study close.

440

441 Conclusions

442 We present an integrated epidemiological and genomic evaluation of the largest dataset of 443 confirmed SARS-CoV-2 imported cases into the UK (or any other country) to our knowledge. 444 We demonstrate the efficacy of closing 'travel-corridors' in reducing onward transmission of 445 imported cases, and highlight the importance for targeted public health campaigns to reduce 446 SARS-CoV-2 importations and onwards transmission. Our data demonstrates how routine 447 genomic monitoring of travel-related cases could be used to refine travel restrictions and the 448 genomic diversity of the SARS-CoV-2 import cases. 
medRxiv preprint doi: https://doi.org/10.1101/2021.03.15.21253590; this version posted March 17, 2021. The copyright holder for this preprint (which was not certified by peer review) is the author/funder, who has granted medRxiv a license to display the preprint in It is made available under a CC-BY-NC-ND 4.0 International license.

Funding

455 DA is a Clinical PhD Fellow and gratefully supported by the Wellcome Trust [Grant number:

$456222903 / Z / 21 / Z]$. EMH is supported by a UK Research and Innovation (UKRI) Fellowship: MR/S00291X/1. AJP, TLV, GMS gratefully acknowledge the support of the Biotechnology and Biological Sciences Research Council (BBSRC); their research was funded by the BBSRC Institute Strategic Programme Microbes in the Food Chain BB/R012504/1 and its constituent project BBS/E/F/000PR10352, also Quadram Institute Bioscience BBSRC funded Core Capability Grant (project number BB/CCG1860/1). The COVID-19 Genomics UK (COG-UK) Consortium is supported by funding from the Medical Research Council (MRC) part of UK Research \& Innovation (UKRI), the National Institute of Health Research (NIHR) and Genome Research Limited, operating as the Wellcome Sanger Institute. The funders had no role in study design, data collection and analysis, decision to publish, or preparation of the manuscript.

\section{Author contributions}

469 All authors read the manuscript and consented to its publication.

470 DA led the study.

471 DA, AJP, GS wrote the first draft of the manuscript.

472 All authors contributed to revision of the first draft of the manuscript.

473 DA, US, AJP, RM, NE undertook data analysis.

474 GMS provided statistical guidance and analysis.

475 DA, SP, NG, EG contributed to data curation.

$476 \mathrm{GJH}, \mathrm{CC}, \mathrm{CT}, \mathrm{SL}, \mathrm{AH}$ provided oversight over data acquisition and data definitions.

477 TLV wrote scripts to perform analysis.

478 NMT undertook the literature search.

479 DA, US, RM, EV, MC, EMH contributed to study design

$480 \mathrm{MC}, \mathrm{EMH}, \mathrm{SJP}$ conceived the study and provided overall leadership.

481 DA, MC and SJP provided clinical oversight.

483 Conflicts of interests and disclosures

484 None declared.

\section{Ethics}

487 This study was conducted as part of surveillance for COVID-19 infections under the 488 auspices of Section 251 of the NHS Act 2006 and/or Regulation 3 of The Health Service 489 (Control of Patient Information) Regulations 2002. They therefore did not require individual 
medRxiv preprint doi: https://doi.org/10.1101/2021.03.15.21253590; this version posted March 17, 2021. The copyright holder for this preprint (which was not certified by peer review) is the author/funder, who has granted medRxiv a license to display the preprint in It is made available under a CC-BY-NC-ND 4.0 International license .

patient consent or ethical approval. Public Health England affiliated authors had access to identifiable patient data. Other authors only had access to anonymised or summerised data. The COG-UK study protocol was approved by the Public Health England Research Ethics Governance Group (reference: R\&D NR0195).

\section{Acknowledgements}

We thank members of the COVID-19 Genomics Consortium UK and Test and Trace contact tracers or their contributions to generating the data used in this study. We thank Sarah Mitchell from the Department of Plant Sciences, University of Cambridge, for direction on statistical analysis.

\section{Data availability}

Assembled/consensus genomes are available from GISAID (22) subject to minimum quality control criteria. Raw reads are available from European Nucleotide Archive (ENA) (23). All genomes, phylogenetic trees, basic metadata are available from the COG-UK consortium website (https://www.cogconsortium.uk/data). For confidentiality reasons, extended metadata (24) is not publicly available, however some may be available upon request from Public Health England.

\section{References}

1. Plessis L du, McCrone JT, Zarebski AE, Hill V, Ruis C, Gutierrez B, et al. Establishment and lineage dynamics of the SARS-CoV-2 epidemic in the UK. Science. $2021 \mathrm{Feb}$ 12;371(6530):708-12.

2. Huang C, Wang Y, Li X, Ren L, Zhao J, Hu Y, et al. Clinical features of patients infected with 2019 novel coronavirus in Wuhan, China. The Lancet. 2020 Feb 15;395(10223):497-506.

3. Zhu N, Zhang D, Wang W, Li X, Yang B, Song J, et al. A Novel Coronavirus from Patients with Pneumonia in China, 2019. N Engl J Med. 2020 Feb 20;382(8):727-33.

4. GOV UK. Coronavirus (COVID-19): travel corridors [Internet]. GOV.UK. 2020 [cited 2020 Nov 19]. Available from: https://www.gov.uk/guidance/coronavirus-covid-19-travelcorridors

5. Smith LE, Potts HW, Amlôt R, Fear NT, Michie S, Rubin GJ. Adherence to the test, trace and isolate system: results from a time series of 21 nationally representative surveys in the UK (the COVID-19 Rapid Survey of Adherence to Interventions and Responses [CORSAIR] study). medRxiv. 2020 Sep 18;2020.09.15.20191957.

6. Border Force. Data on health measures at the UK border [Internet]. GOV.UK. 2020 [cited 2021 Feb 19]. Available from: https://www.gov.uk/government/publications/data-onhealth-measures-at-the-uk-border/data-on-health-measures-at-the-uk-border 
medRxiv preprint doi: https://doi.org/10.1101/2021.03.15.21253590; this version posted March 17, 2021. The copyright holder for this preprint (which was not certified by peer review) is the author/funder, who has granted medRxiv a license to display the preprint in

It is made available under a CC-BY-NC-ND 4.0 International license.

7. To KK-W, Hung IF-N, Ip JD, Chu AW-H, Chan W-M, Tam AR, et al. COVID-19 reinfection by a phylogenetically distinct SARS-coronavirus-2 strain confirmed by whole genome sequencing. Clin Infect Dis [Internet]. 2020 Aug 25 [cited 2020 Sep 8]; Available from: https://academic.oup.com/cid/advancearticle/doi/10.1093/cid/ciaa1275/5897019

8. Hodcroft EB, Zuber M, Nadeau S, Comas I, Candelas FG, Consortium S-S, et al. Emergence and spread of a SARS-CoV-2 variant through Europe in the summer of 2020. medRxiv. 2020 Oct 28;2020.10.25.20219063.

9. COG-UK. An integrated national scale SARS-CoV-2 genomic surveillance network. Lancet Microbe [Internet]. 2020 Jun 2 [cited 2020 Jun 9];0(0). Available from: https://www.thelancet.com/journals/lanmic/article/PIIS2666-5247(20)30054-9/abstract

10. Quick J. nCoV-2019 sequencing protocol v2. 2020 Apr 9 [cited 2020 Apr 25]; Available from: https://www.protocols.io/view/ncov-2019-sequencing-protocol-v2-bdp7i5rn

11. Bonsall D, Golubchik T, Cesare M de, Limbada M, Kosloff B, Maclntyre-Cockett G, et al. A Comprehensive Genomics Solution for HIV Surveillance and Clinical Monitoring in Low-Income Settings. J Clin Microbiol [Internet]. 2020 Sep 22 [cited $2021 \mathrm{Mar}$ 10];58(10). Available from: https://jcm.asm.org/content/58/10/e00382-20

12. Nicholls SM, Poplawski R, Bull MJ, Underwood A, Chapman M, Abu-Dahab K, et al. MAJORA: Continuous integration supporting decentralised sequencing for SARS-CoV2 genomic surveillance. bioRxiv. 2020 Oct 7;2020.10.06.328328.

13. Connor TR, Loman NJ, Thompson S, Smith A, Southgate J, Poplawski R, et al. CLIMB (the Cloud Infrastructure for Microbial Bioinformatics): an online resource for the medical microbiology community. Microb Genomics. 2016;2(9):e000086.

14. Rambaut A, Holmes EC, O'Toole Á, Hill V, McCrone JT, Ruis C, et al. A dynamic nomenclature proposal for SARS-CoV-2 lineages to assist genomic epidemiology. Nat Microbiol. 2020 Nov;5(11):1403-7.

15. Brooks ME, Kristensen K, Van Benthem KJ, Magnusson A, Berg CW, Nielsen A, et al. glmmTMB balances speed and flexibility among packages for zero-inflated generalized linear mixed modeling. R J. 2017;9(2):378-400.

16. Lenth $\mathrm{R}$, Singmann $\mathrm{H}$, Love J, Buerkner $\mathrm{P}$, Herve M. Emmeans: Estimated marginal means, aka least-squares means. R Package Version. 2018;1(1):3.

17. Team RC. R: a language and environment for statistical computing. R Foundation for Statistical Computing, Vienna. WwwR-Proj. 2018;

18. Foreign \& Commonwealth Office. Travel advice: coronavirus (COVID-19) [Internet]. GOV.UK. 2021 [cited 2021 Feb 19]. Available from: https://www.gov.uk/guidance/travel-advice-novel-coronavirus

19. Office for National Statistics, National Records of Scotland, Northern Ireland Statistics and Research Agency. 2011 Census aggegate data (Data downloaded: 1 June 2016) [Internet]. UK Data Service; 2016. Available from: https://beta.ukdataservice.ac.uk/datacatalogue/studies/study?id=7427

20. DHSC, SAGE. The $R$ value and growth rate in the UK [Internet]. GOV.UK. 2021 [cited $2021 \mathrm{Feb}$ 19]. Available from: https://www.gov.uk/guidance/the-r-number-in-the-uk 
medRxiv preprint doi: https://doi.org/10.1101/2021.03.15.21253590; this version posted March 17, 2021. The copyright holder for this preprint (which was not certified by peer review) is the author/funder, who has granted medRxiv a license to display the preprint in

It is made available under a CC-BY-NC-ND 4.0 International license.

21. GOV UK. Sero-surveillance of COVID-19 [Internet]. GOV.UK. 2020 [cited 2020 Nov 19]. Available from: https://www.gov.uk/government/publications/national-covid-19surveillance-reports/sero-surveillance-of-covid-19

22. Shu Y, McCauley J. GISAID: Global initiative on sharing all influenza data - from vision to reality. Eurosurveillance. 2017 Mar 30;22(13):30494.

23. Cochrane G, Karsch-Mizrachi I, Takagi T, Sequence Database Collaboration IN. The International Nucleotide Sequence Database Collaboration. Nucleic Acids Res. 2016 Jan 4;44(D1):D48-50.

24. Griffiths EJ, Timme RE, Page AJ, Alikhan N-F, Fornika D, Maguire F, et al. The PHA4GE SARS-CoV-2 Contextual Data Specification for Open Genomic Epidemiology. 2020 Aug 9 [cited 2020 Sep 3]; Available from: https://www.preprints.org/manuscript/202008.0220/v1

25. Au CH, Chan WS, Lam HY, Ho DN, Lam SYM, Zee JST, et al. Genome Sequences of SARS-CoV-2 Strains Detected in Hong Kong. Microbiol Resour Announc. 2020 Jul;9(31):e00697-20.

26. Böhmer MM, Buchholz U, Corman VM, Hoch M, Katz K, Marosevic DV, et al. Investigation of a COVID-19 outbreak in Germany resulting from a single travelassociated primary case: a case series. Lancet Infect Dis. 2020;20(8):920-8.

27. Cohen-Gihon I, Israeli O, Shifman O, Stein D, Achdout H, Weiss S, et al. CodingComplete Genome Sequences of Two SARS-CoV-2 Isolates from Early Manifestations of COVID-19 in Israel. Microbiol Resour Announc. 2020 Jul;9(28):e00677-20.

28. Jesus JG de, Sacchi C, Candido D da S, Claro IM, Sales FCS, Manuli ER, et al. Importation and early local transmission of COVID-19 in Brazil, 2020. Rev Inst Med Trop Sao Paulo. 2020;62:e30.

29. do Nascimento VA, Guerra Corado A de L, do Nascimento FO, Araujo da Costa AK, Gomes Duarte DC, Bessa Luz SL, et al. Genomic and phylogenetic characterisation of an imported case of SARS-CoV-2 in Amazonas State, Brazil. Mem Inst Oswaldo Cruz. 2020;115:e200310.

30. Du P, Ding N, Li J, Zhang F, Wang Q, Chen Z, et al. Genomic surveillance of COVID19 cases in Beijing. Nat Commun. 2020 30;11(1):5503.

31. Garcés-Ayala F, Araiza-Rodríguez A, Mendieta-Condado E, Rodríguez-Maldonado AP, Wong-Arámbula $\mathrm{C}$, Landa-Flores $\mathrm{M}$, et al. Full genome sequence of the first SARSCoV-2 detected in Mexico. Arch Virol. 2020 Sep;165(9):2095-8.

32. Giandhari J, Pillay S, Wilkinson E, Tegally H, Sinayskiy I, Schuld M, et al. Early transmission of SARS-CoV-2 in South Africa: An epidemiological and phylogenetic report. Int J Infect Dis. 2021 Feb 1;103:234-41.

33. Giovanetti M, Benvenuto D, Angeletti S, Ciccozzi M. The first two cases of 2019-nCoV in Italy: Where they come from? J Med Virol. 2020;92(5):518-21.

34. Gómez-Carballa A, Bello X, Pardo-Seco J, Pérez Del Molino ML, Martinón-Torres F, Salas A. Phylogeography of SARS-CoV-2 pandemic in Spain: a story of multiple introductions, micro-geographic stratification, founder effects, and super-spreaders. Zool Res. 2020 Nov 18;41(6):605-20. 
medRxiv preprint doi: https://doi.org/10.1101/2021.03.15.21253590; this version posted March 17, 2021. The copyright holder for this preprint (which was not certified by peer review) is the author/funder, who has granted medRxiv a license to display the preprint in It is made available under a CC-BY-NC-ND 4.0 International license .

612

613

614

615

616

617

618

619

620

621

622

623

624

625

626

627

628

629

630

631

632

633

634

635

636

637

638

639

640

641

642

643

644

645

646

647

648

649

650

651

652

653

35. Gong Y-N, Tsao K-C, Hsiao M-J, Huang C-G, Huang P-N, Huang P-W, et al. SARSCoV-2 genomic surveillance in Taiwan revealed novel ORF8-deletion mutant and clade possibly associated with infections in Middle East. Emerg Microbes Infect. 2020 Jan 1;9(1):1457-66.

36. Jia Y, Yang C, Zhang M, Yang X, Li J, Liu J, et al. Characterization of eight novel fulllength genomes of SARS-CoV-2 among imported COVID-19 cases from abroad in Yunnan, China. J Infect. 2020;81(2):e96-8.

37. Kouriba B, Dürr A, Rehn A, Sangaré AK, Traoré BY, Bestehorn-Willmann MS, et al. First Phylogenetic Analysis of Malian SARS-CoV-2 Sequences Provides Molecular Insights into the Genomic Diversity of the Sahel Region. Viruses. 2020 Nov;12(11):1251.

38. Kumar P, Pandey R, Sharma P, Dhar MS, A V, Uppili B, et al. Integrated genomic view of SARS-CoV-2 in India. Wellcome Open Res. 2020;5:184.

39. Liu J, Huang J, Xiang D. Large SARS-CoV-2 outbreak caused by asymptomatic traveler, China. Emerg Infect Dis. 2020;26(9):2260-3.

40. Lu J, du Plessis L, Liu Z, Hill V, Kang M, Lin H, et al. Genomic Epidemiology of SARSCoV-2 in Guangdong Province, China. Cell. 2020 May 28;181(5):997-+.

41. Manning JE, Bohl JA, Lay S, Chea S, Sovann L, Sengdoeurn Y, et al. Rapid metagenomic characterization of a case of imported COVID-19 in Cambodia. BioRxiv Prepr Serv Biol. 2020 Mar 5;

42. Marquez S, Prado-Vivar B, Guadalupe JJ, Gutierrez Granja B, Jibaja M, Tobar M, et al. Genome sequencing of the first SARS-CoV-2 reported from patients with COVID-19 in Ecuador. MedRxiv Prepr Serv Health Sci. 2020 Jun 14;

43. Puenpa J, Suwannakarn K, Chansaenroj J, Nilyanimit P, Yorsaeng R, Auphimai C, et al. Molecular epidemiology of the first wave of severe acute respiratory syndrome coronavirus 2 infection in Thailand in 2020. Sci Rep. 2020 Oct 6;10(1):16602.

44. Rockett RJ, Arnott A, Lam C, Sadsad R, Timms V, Gray K-A, et al. Revealing COVID19 transmission in Australia by SARS-CoV-2 genome sequencing and agent-based modeling. Nat Med. 2020;26(9):1398-404.

45. Seemann T, Lane CR, Sherry NL, Duchene S, da Silva AG, Caly L, et al. Tracking the COVID-19 pandemic in Australia using genomics. Nat Commun. 2020 Sep $1 ; 11(1): 4376$.

46. Sekizuka T, Kuramoto S, Nariai E, Taira M, Hachisu Y, Tokaji A, et al. SARS-CoV-2 Genome Analysis of Japanese Travelers in Nile River Cruise. Front Microbiol. 2020 Jun $5 ; 11: 1316$.

47. Stange M, Mari A, Roloff T, Seth-Smith HM, Schweitzer M, Brunner M, et al. SARSCoV-2 outbreak in a tri-national urban area is dominated by a B.1 lineage variant linked to mass gathering events. medRxiv. 2020 Nov 4;2020.09.01.20186155. 
medRxiv preprint doi: https://doi.org/10.1101/2021.03.15.21253590; this version posted March 17, 2021. The copyright holder for this preprint (which was not certified by peer review) is the author/funder, who has granted medRxiv a license to display the preprint in It is made available under a CC-BY-NC-ND 4.0 International license

654

655
656

657

658

659

660

661

Tables

\begin{tabular}{|c|c|c|c|c|c|}
\hline \multirow[t]{2}{*}{ Country } & \multicolumn{2}{|r|}{ Cases } & \multicolumn{2}{|c|}{$\begin{array}{c}\text { Sequenced samples } \\
\text { from cases (passed } \\
\text { QC) }\end{array}$} & \multirow{2}{*}{$\begin{array}{r}\begin{array}{c}\text { Percentage of } \\
\text { cases sequenced } \\
\text { by country of travel }\end{array} \\
18.8 \%\end{array}$} \\
\hline & $\mathbf{N}$ & $\%$ & $\mathbf{N}$ & $\%$ & \\
\hline Greece & 882 & $21.0 \%$ & 166 & $20.1 \%$ & $23.6 \%$ \\
\hline Croatia & 685 & $16.3 \%$ & 162 & $19.6 \%$ & $18.0 \%$ \\
\hline Spain & 589 & $14.0 \%$ & 106 & $12.8 \%$ & $20.2 \%$ \\
\hline Unknown & 282 & $6.7 \%$ & 57 & $6.9 \%$ & $23.3 \%$ \\
\hline France & 223 & $5.3 \%$ & 52 & $6.3 \%$ & $11.2 \%$ \\
\hline Turkey & 187 & $4.4 \%$ & 21 & $2.5 \%$ & $18.0 \%$ \\
\hline Portugal & 111 & $2.6 \%$ & 20 & $2.4 \%$ & $15.2 \%$ \\
\hline Malta & 99 & $2.4 \%$ & 15 & $1.8 \%$ & $22.6 \%$ \\
\hline Italy & 93 & $2.2 \%$ & 21 & $2.5 \%$ & $16.5 \%$ \\
\hline Poland & 85 & $2.0 \%$ & 14 & $1.7 \%$ & $16.7 \%$ \\
\hline Romania & 78 & $1.9 \%$ & 13 & $1.6 \%$ & $15.4 \%$ \\
\hline $\begin{array}{l}\text { Czech } \\
\text { Republic }\end{array}$ & 65 & $1.5 \%$ & 10 & $1.2 \%$ & $19.7 \%$ \\
\hline Albania & 61 & $1.4 \%$ & 12 & $1.5 \%$ & $27.9 \%$ \\
\hline Hungary & 61 & $1.4 \%$ & 17 & $2.1 \%$ & $24.6 \%$ \\
\hline India & 57 & $1.4 \%$ & 14 & $1.7 \%$ & $21.8 \%$ \\
\hline Pakistan & 55 & $1.3 \%$ & 12 & $1.5 \%$ & $13.2 \%$ \\
\hline Netherlands & 38 & $0.9 \%$ & 5 & $0.6 \%$ & $20.7 \%$ \\
\hline Germany & 29 & $0.7 \%$ & 6 & $0.7 \%$ & $25.0 \%$ \\
\hline Switzerland & 28 & $0.7 \%$ & 7 & $0.8 \%$ & $12.5 \%$ \\
\hline Kosovo & 24 & $0.6 \%$ & 3 & $0.4 \%$ & $18.8 \%$ \\
\hline Total cases & 4207 & & 827 & & $19.7 \%$ \\
\hline
\end{tabular}

Table 1: The top 20 countries reported as the travel destination for importations of SARS-CoV-2 into England and the associated number of samples sequenced from travel-related cases

\begin{tabular}{|l|c|c|c|}
\hline \multicolumn{1}{|c|}{ Demographic } & $\begin{array}{c}\text { Cas } \\
\text { es }\end{array}$ & $\begin{array}{c}\text { Total contacts of } \\
\text { cases }\end{array}$ & $\begin{array}{c}\text { contacts reported } \\
\text { per case }\end{array}$ \\
\hline Sex & \multicolumn{3}{|c|}{} \\
\hline Male & 2193 & 9835 & 4.5 \\
\hline Female & 1933 & 8578 & 4.4 \\
\hline Unknown & 82 & 224 & 3.1 \\
\hline Age & \multicolumn{3}{|l}{} \\
\hline $0-5$ & 51 & 183 & 3.6 \\
\hline
\end{tabular}


medRxiv preprint doi: https://doi.org/10.1101/2021.03.15.21253590; this version posted March 17, 2021. The copyright holder for this preprint (which was not certified by peer review) is the author/funder, who has granted medRxiv a license to display the preprint in It is made available under a CC-BY-NC-ND 4.0 International license.

\begin{tabular}{|c|c|c|c|}
\hline $6-10$ & 45 & 124 & 2.8 \\
\hline $11-15$ & 75 & 321 & 4.3 \\
\hline $16-20$ & 1086 & 7473 & 6.9 \\
\hline $21-25$ & 843 & 3536 & 4.2 \\
\hline $26-30$ & 685 & 2091 & 3.1 \\
\hline $31-35$ & 413 & 1312 & 3.2 \\
\hline $36-40$ & 278 & 939 & 3.4 \\
\hline $41-45$ & 185 & 566 & 3.1 \\
\hline $46-50$ & 169 & 723 & 4.3 \\
\hline $51-55$ & 130 & 469 & 3.6 \\
\hline $56-60$ & 121 & 434 & 3.6 \\
\hline $61-65$ & 57 & 229 & 4.0 \\
\hline $66-70$ & 30 & 116 & 3.9 \\
\hline $71-75$ & 20 & 63 & 3.2 \\
\hline $76-80$ & 7 & 16 & 2.3 \\
\hline $81-85$ & 7 & 39 & 5.6 \\
\hline $86-90$ & 3 & 3 & 1.0 \\
\hline $91-95$ & 0 & 0 & NA \\
\hline Unknown & 2 & & \\
\hline \multicolumn{4}{|l|}{ Ethnic group } \\
\hline \multicolumn{4}{|l|}{ White } \\
\hline $\begin{array}{l}\text { English/Welsh/Scottish/Northern } \\
\text { Irish/British }\end{array}$ & 2509 & 12745 & 5.1 \\
\hline Irish & 35 & 121 & 3.5 \\
\hline Gypsy or Irish Traveller & 0 & 0 & $\mathrm{NA}$ \\
\hline Any other White background & 583 & 1755 & 3.0 \\
\hline \multicolumn{4}{|l|}{ Mixed/Multiple ethnic groups } \\
\hline White and Black Caribbean & 42 & 284 & 6.8 \\
\hline White and Black African & 25 & 108 & 4.3 \\
\hline White and Asian & 49 & 216 & 4.4 \\
\hline $\begin{array}{l}\text { Any other Mixed/Multiple ethnic } \\
\text { background }\end{array}$ & 44 & 147 & 3.3 \\
\hline \multicolumn{4}{|l|}{ Asian/Asian British } \\
\hline Indian & 103 & 481 & 4.7 \\
\hline Pakistani & 79 & 306 & 3.9 \\
\hline Bangladeshi & 27 & 82 & 3.0 \\
\hline Chinese & 6 & 2 & 0.3 \\
\hline Any other Asian background & 62 & 199 & 3.2 \\
\hline \multicolumn{4}{|l|}{$\begin{array}{l}\text { Black/ African/Caribbean/Black } \\
\text { British }\end{array}$} \\
\hline African & 58 & 152 & 2.6 \\
\hline Caribbean & 12 & 36 & 3.0 \\
\hline
\end{tabular}


medRxiv preprint doi: https://doi.org/10.1101/2021.03.15.21253590; this version posted March 17, 2021. The copyright holder for this preprint (which was not certified by peer review) is the author/funder, who has granted medRxiv a license to display the preprint in It is made available under a CC-BY-NC-ND 4.0 International license

\begin{tabular}{|c|c|c|c|}
\hline $\begin{array}{l}\text { Any other Black/African/Caribbean } \\
\text { background }\end{array}$ & 12 & 28 & 2.3 \\
\hline \multicolumn{4}{|l|}{ Other ethnic group } \\
\hline Arab & 0 & 0 & NA \\
\hline Any other ethnic group & 110 & 367 & 3.3 \\
\hline \multicolumn{4}{|l|}{ Other } \\
\hline Prefer not to say & 65 & 135 & 2.1 \\
\hline Unknown & 386 & 1473 & 3.8 \\
\hline \multicolumn{4}{|l|}{ Region } \\
\hline London & 1205 & 4275 & 3.5 \\
\hline South East & 622 & 3211 & 5.2 \\
\hline North West & 584 & 2323 & 4.0 \\
\hline East of England & 395 & 2079 & 5.3 \\
\hline South West & 328 & 1960 & 6.0 \\
\hline Yorkshire and Humber & 327 & 1411 & 4.3 \\
\hline West Midlands & 299 & 1259 & 4.2 \\
\hline East Midlands & 251 & 1351 & 5.4 \\
\hline North East & 161 & 660 & 4.1 \\
\hline Not stated & 35 & 108 & 3.1 \\
\hline \multicolumn{4}{|l|}{ Country } \\
\hline Greece & 882 & 5587 & 6.3 \\
\hline Croatia & 685 & 3913 & 5.7 \\
\hline Spain & 589 & 1521 & 2.6 \\
\hline Unknown & 282 & 988 & 3.5 \\
\hline France & 223 & 815 & 3.7 \\
\hline Turkey & 187 & 702 & 3.8 \\
\hline Portugal & 111 & 439 & 4.0 \\
\hline Malta & 99 & 492 & 5.0 \\
\hline Italy & 93 & 390 & 4.2 \\
\hline Poland & 85 & 417 & 4.9 \\
\hline Romania & 78 & 189 & 2.4 \\
\hline Hungary & 67 & 137 & 2.0 \\
\hline Czech Republic & 66 & 239 & 3.6 \\
\hline Albania & 61 & 140 & 2.3 \\
\hline India & 57 & 223 & 3.9 \\
\hline Pakistan & 55 & 269 & 4.9 \\
\hline Netherlands & 38 & 166 & 4.4 \\
\hline Germany & 29 & 101 & 3.5 \\
\hline
\end{tabular}


medRxiv preprint doi: https://doi.org/10.1101/2021.03.15.21253590; this version posted March 17, 2021. The copyright holder for this preprint (which was not certified by peer review) is the author/funder, who has granted medRxiv a license to display the preprint in perpetuity.

It is made available under a CC-BY-NC-ND 4.0 International license

\begin{tabular}{|l|c|c|c|}
\hline Switzerland & 28 & 123 & 4.4 \\
\hline Kosovo & 24 & 64 & 2.7 \\
\hline
\end{tabular}

\section{Figures}

996 probable imported cases

reporting travel within 7 days of test/symptom onset

- 71 duplicate

925 probable imported cases
4811 probable imported cases reporting travel within 2 days of test/symptom onset

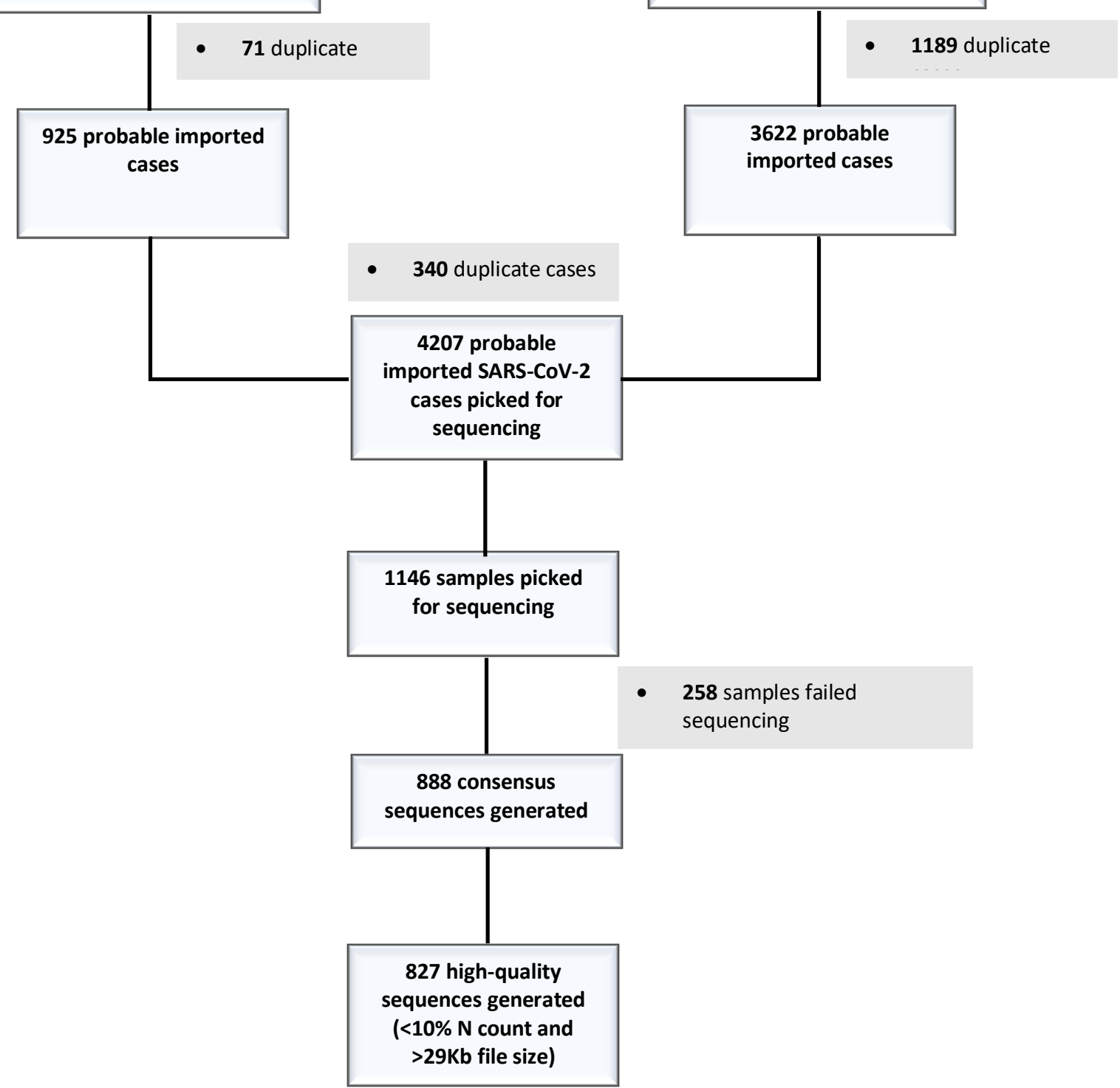

Figure 1a: Flow diagram of travel-related case ascertainment from Test and Trace data and subsequent genome availability. Cases were defined as 'highly probable' and 'probable'. 'Highly probable' travel-related cases were defined as individuals who reported international travel as an activity in the two days before symptom onset/testing. On $12 / 08 / 2020$ the additional facility to report international travel in the seven days prior to symptom onset/testing became available, and also included in this study and defined as 'probable' travel-related cases. 
medRxiv preprint doi: https://doi.org/10.1101/2021.03.15.21253590; this version posted March 17, 2021. The copyright holder for this preprint (which was not certified by peer review) is the author/funder, who has granted medRxiv a license to display the preprint in perpetuity.

It is made available under a CC-BY-NC-ND 4.0 International license

674

675

676

677

678

679

680

681

682

683

684

685

686

687

688

\begin{tabular}{|c|c|c|c|c|c|c|c|c|c|}
\hline & May 2020 & June 2020 & July 2020 & $\begin{array}{l}\text { August } \\
2020\end{array}$ & $\begin{array}{l}\text { September } \\
2020\end{array}$ & $\begin{array}{l}\text { October } \\
2020\end{array}$ & $\begin{array}{l}\text { November } \\
2020\end{array}$ & $\begin{array}{l}\text { December } \\
2020\end{array}$ & $\begin{array}{l}\text { January } \\
2021\end{array}$ \\
\hline \multicolumn{10}{|l|}{$\begin{array}{l}\text { Study } \\
\text { Period }\end{array}$} \\
\hline \multicolumn{10}{|l|}{$\begin{array}{l}\text { Travel } \\
\text { Corridors* }\end{array}$} \\
\hline $\begin{array}{l}\text { Test and } \\
\text { release }\end{array}$ & & & & & & & & & \\
\hline
\end{tabular}

- 82 duplicate contacts

- 2 contacts could not be matched to import cases

18855 contacts of 4207 probable travel-related cases

Figure 1b: Flow diagram relaying contacts ascertained of cases from Test and Trace data

689

690 Figure 1c: Timeline of study period (27/05/2020 to 13/09/2020) and associated policy

691 changes on travel introduced in England. Travel restrictions were assigned on a country

692 by country basis from 6 July 2020. Travellers returning from countries that were on the travel

693 restrictions list (4) were required to self-isolate for 14 days ("

$69415 / 12 / 20$ ), or from the $15^{\text {th }}$ December 2020, choose to self-isolate for 5 days and then pay

695 for a SARS-CoV-2 diagnostic test (test and release)

696

697 
medRxiv preprint doi: https://doi.org/10.1101/2021.03.15.21253590; this version posted March 17, 2021. The copyright holder for this preprint (which was not certified by peer review) is the author/funder, who has granted medRxiv a license to display the preprint in perpetuity.

It is made available under a CC-BY-NC-ND 4.0 International license .

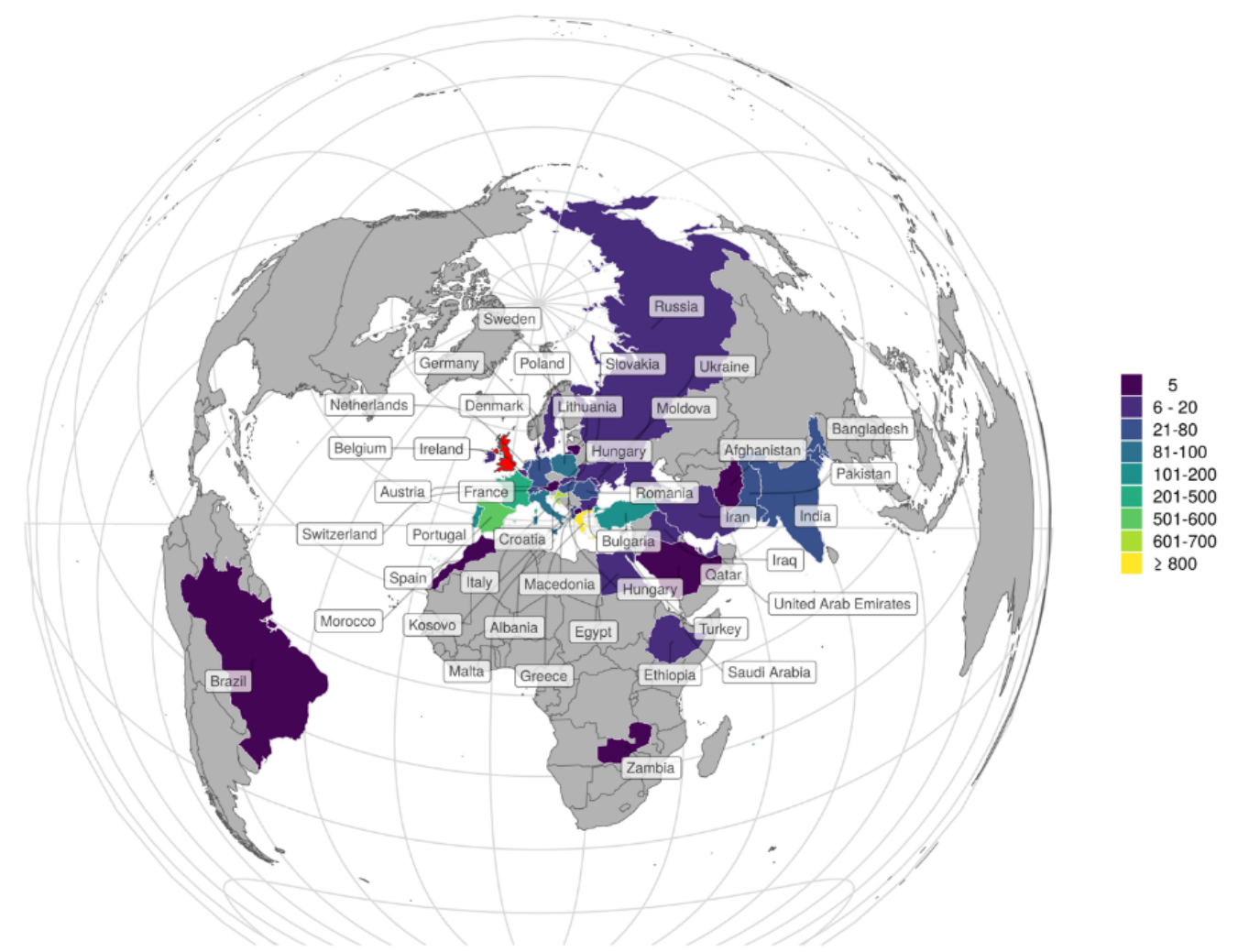

698

699

Figure 2a: Countries where importations originated. Countries with less than 5 importations were excluded for confidentiality reasons.

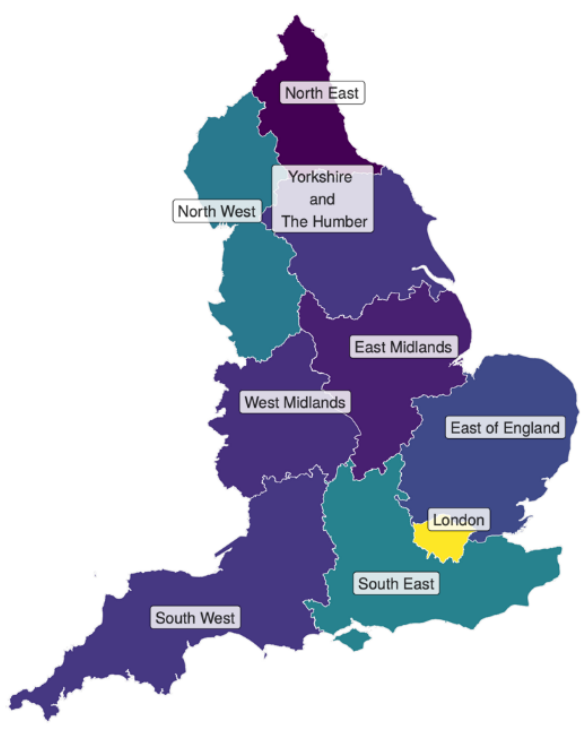

701

Figure 2b: Destinations of imported cases within England. Areas with less than 3 
medRxiv preprint doi: https://doi.org/10.1101/2021.03.15.21253590; this version posted March 17, 2021. The copyright holder for this preprint (which was not certified by peer review) is the author/funder, who has granted medRxiv a license to display the preprint in It is made available under a CC-BY-NC-ND 4.0 International license .

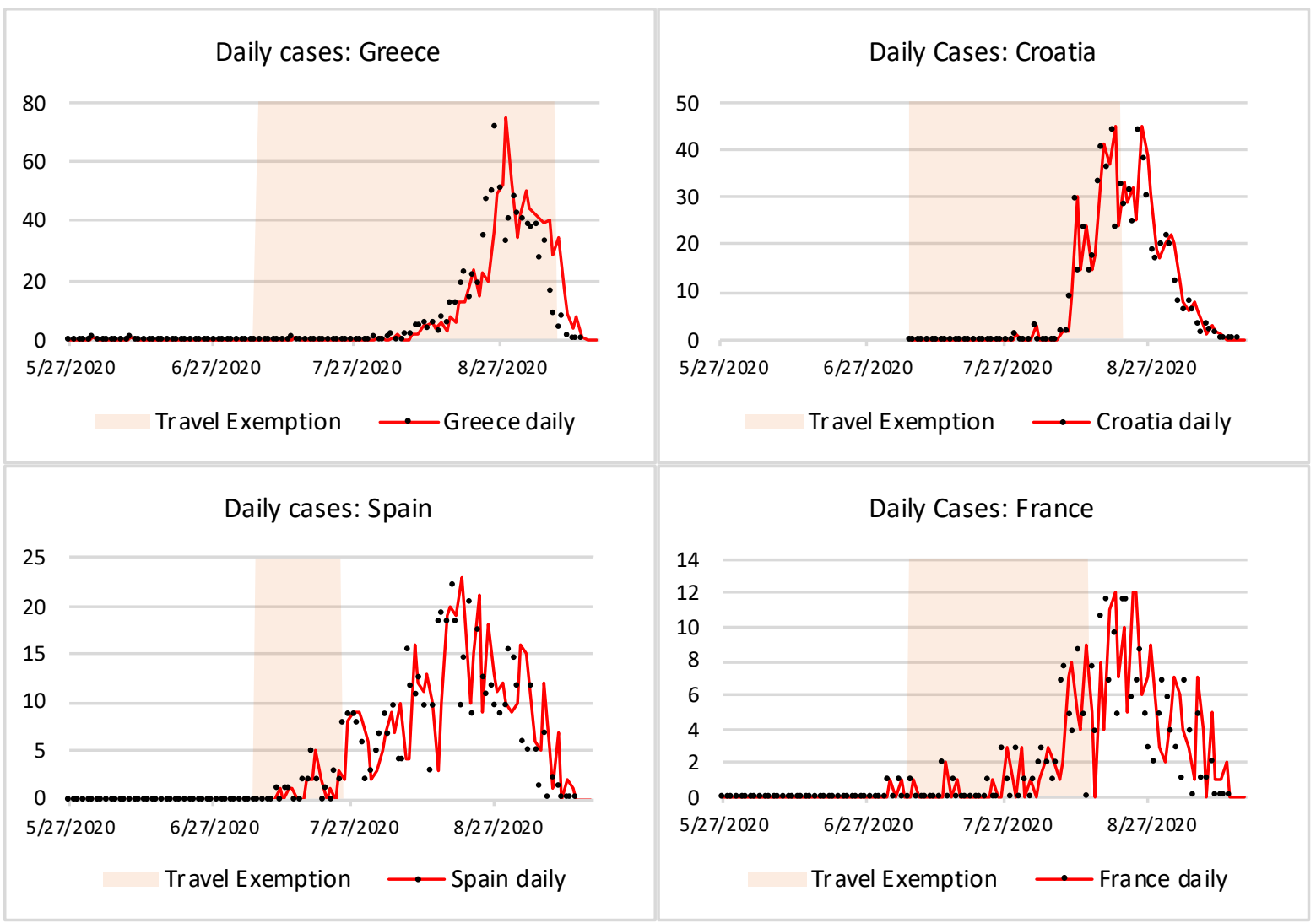

Figure 3: Frequency of importations over time for the top 4 most common countries of travel reported by individuals testing positive for SARS-CoV-2 during the study period. SARS-CoV-2 case numbers in returning travellers by the four most popular countries of travel reported by cases representing $2379 / 4207(56.5 \%)$ of known travelrelated cases. The shaded areas represent the period of time when the countries did not have restrictive travel guidance in place.

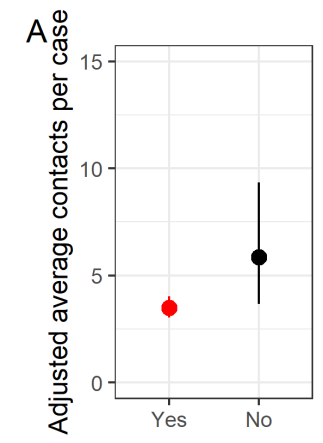

Travel restriction
$\mathrm{B}$

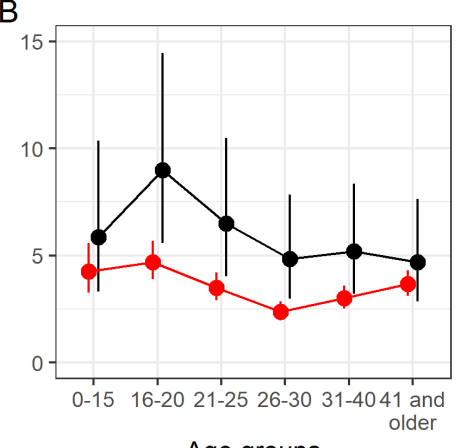

C

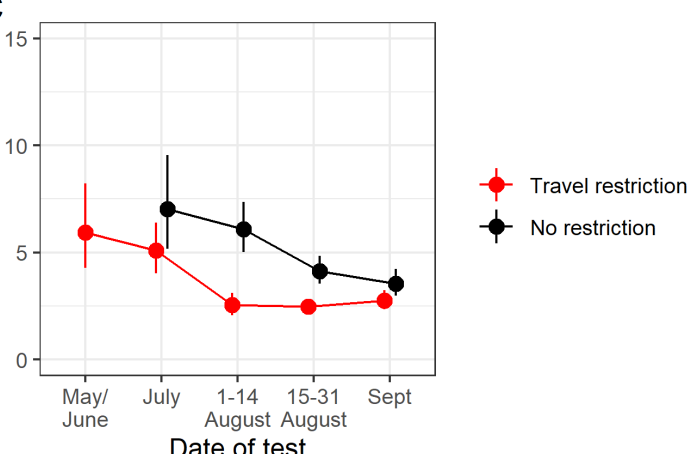

Figure 4: The effect of travel restriction on contacts per imported case of SARS-CoV-

2. Estimated marginal mean number of contacts per imported case (a) overall, (b) by agegroup and (c) by date of test comparing countries with travel restriction guidance (closed 'travel-corridors') in place and those without (open 'travel-corridors). All estimates are provided with $95 \%$ confidence intervals. 
medRxiv preprint doi: https://doi.org/10.1101/2021.03.15.21253590; this version posted March 17, 2021. The copyright holder for this preprint (which was not certified by peer review) is the author/funder, who has granted medRxiv a license to display the preprint in It is made available under a CC-BY-NC-ND 4.0 International license .
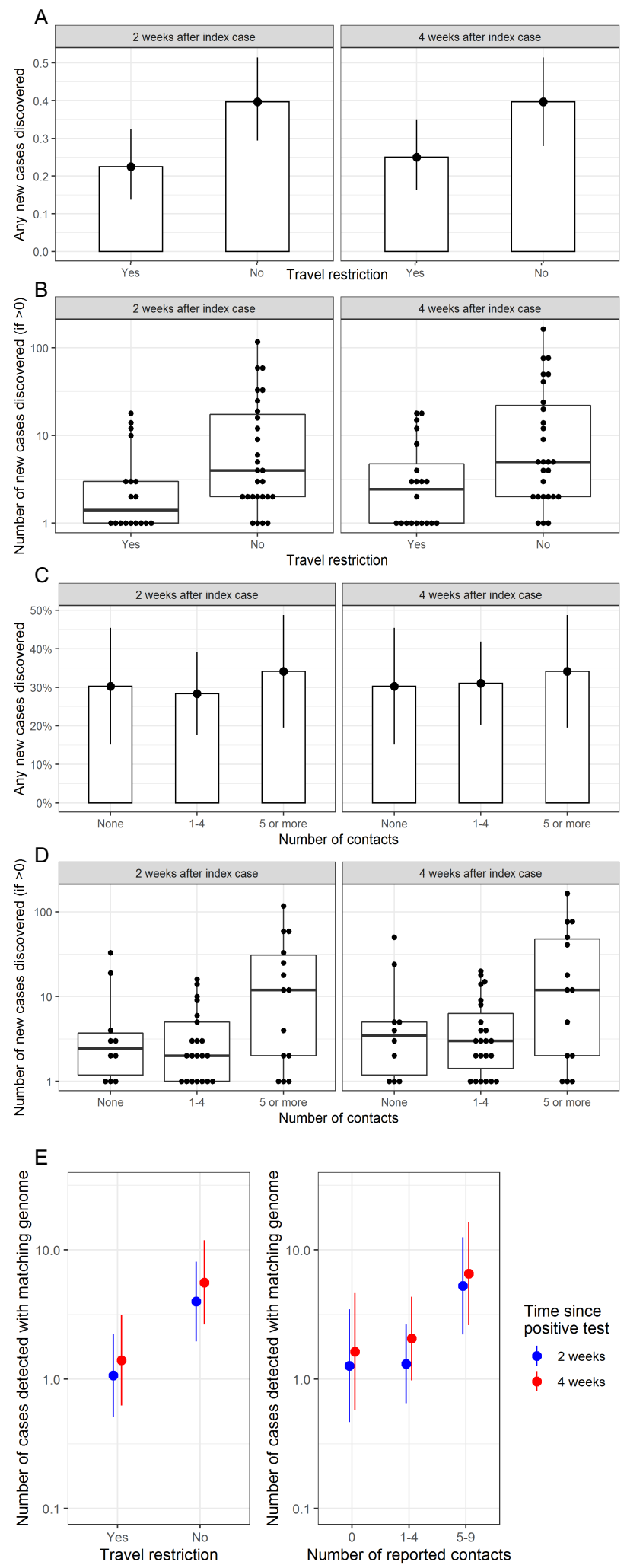

Figure 5: The effect of travel restrictions on the subsequent spread of likely imported cases as determined by genomics. Panel $A$ : The proportion of imported cases with any matching genome detected over the two or four weeks following index test result. Panel $B$ : The number of genomes matching the index case, with zeros excluded. Panel A and $B$ compare countries with travel restriction guidance (closed 'travel-corridors') in place and those without (open 'travel-corridors). Panel C: The proportion of imported cases with any matching genome detected over the two of four weeks following index test result. Panel D: 
medRxiv preprint doi: https://doi.org/10.1101/2021.03.15.21253590; this version posted March 17, 2021. The copyright holder for this preprint (which was not certified by peer review) is the author/funder, who has granted medRxiv a license to display the preprint in It is made available under a CC-BY-NC-ND 4.0 International license The number of genomes matching the index case, with zeros excluded. Panel E: Estimated marginal mean number of genomes detected after 2 weeks or 4 weeks matching an index genome, stratified by travel restriction and stratified by number of contacts. In all panels, boxes correspond to median and interquartile range, and error bars correspond to $95 \%$ confidence intervals. 